\title{
Introduction: Consequences of low turnout
}

\author{
Georg Lutz ${ }^{\mathrm{a}}$, Michael Marsh ${ }^{\mathrm{b}, *}$ \\ a Institute of Political Science, University of Bern, Lerchenweg 36, CH-3000 Berne 9, Switzerland \\ ${ }^{\mathrm{b}}$ Department of Political Science, Trinity College Dublin, 1 College Green, Dublin 2, Ireland
}

\begin{abstract}
Low electoral turnout has become common in many countries. Whether this is a problem for a democracy depends on-among other things - whether higher turnout would have made other parties more relevant. This introductory article discusses the findings and approaches of previous work on this question and summarizes the findings of the work published in this issue. The various articles, despite using different approaches, looking at different countries and different types of election, all show that any bias in election outcomes is typically rather small and is not in a specific direction: sometimes the left would benefit from higher turnout, sometimes other parties. Therefore the concerns about potential bias consequent on low turnout are generally misplaced.
\end{abstract}

(c) 2006 Elsevier Ltd. All rights reserved.

Keywords: Low turnout; Partisan bias; Democracy

\section{Low and decreasing turnout and why it may matter}

Countries like Switzerland and the US have long had turnout rates below $50 \%$ for national elections, but in recent years low turnout in national elections has become much more widespread. Blais et al. (2004) and Gray and Caul (2000) found a downward trend in national election turnout, and countries such as the UK and Finland, which appeared to have resisted this trend, have experienced a sudden drop in turnout in recent national elections. Most countries also have second-order contests such as European Parliament elections or local elections with particularly low turnout rates.

\footnotetext{
* Corresponding author. Tel.: +3531896 1070; fax: +35316770546.

E-mail addresses: georg.lutz@ipw.unibe.ch (G. Lutz), mmarsh@ tcd.ie (M. Marsh).
}

As turnout falls, concerns about the functioning of democracy are rising. In a much cited article based on his 1996 APSA Presidential address Arend Lijphart calls low turnout a serious democratic problem and democracy's "unresolved dilemma" (Lijphart, 1997, 1), the reason being that it makes the operation of electoral democracy unequal: some voices are heard and others are silent. In the eyes of many democratic theorists (Barber, 1984; Pateman, 1970) participation is essential for democracy and there is a general feeling among many politicians and political commentators that high turnout is important for democracies. It is suggested that the legitimacy of democracy in general and the outcomes of elections in particular are undermined when many citizens do not participate (Cavanagh, 1981, 62; Salisbury, 1975, 326).

While these observations stem in part from a normative commitment to participation in general and voting in particular per se, they also stem from the assumption that, in Lijphart's terms, if they were to speak the 
'silent' would have a different voice to that of the 'heard'. It is this aspect of the possible consequences of low turnout that are the main focus of this special issue. More specifically, we look at whether turnout matters for the outcome of the political process, especially elections. It should not simply be assumed that the preferences of the non-voters are any different than the preferences of the voters and hence greater or even full turnout would make a difference.

The standard view is that low turnout produces a class bias in electoral outcomes. Most studies of participation have found that socio-economic status (SES) is strongly correlated to participation. Education, income, age and sometimes gender are highly significant predictors of whether somebody voted (Franklin, 2002; Norris, 2002, 83ff). If it is assumed that the political system listens more closely to the voices of those who participate, unequal turnout spells unequal influence of the less-well-do citizens (Lijphart, 1997, 1; Verba et al., 1995, 11). Because low SES voters traditionally voted for left wing socialist and social democratic parties, low turnout should lead to a bias against left wing parties and left wing policies in consequence.

At this point it is sensible to review the nature of the puzzle we are trying to solve. We want to find out if low turnout is a problem and we assume that it would be a problem if higher levels of turnout would bring different election or policy outcomes. More particular variations of this question focus on the more specific or directional possibility that left-of-centre parties would do better if turnout increased, as well as how big the difference would be-whether they would be sufficiently substantial to have effects on government formation or policy outcomes-and whether we can predict under which situational and institutional circumstances turnout effects are a factor that is to be reckoned with. Another variation of this question would be to explore what would happen if turnout was to be (even) lower than the current level in an election (see van der Eijk and van Egmond, in this issue). Given declining turnout in many countries, this question might be of even more practical relevance than the question of what would happen if turnout would rise in low-turnout countries.

There are three different underlying aspects of the general problem and they are not of necessity related: (1) Do voters have different party or policy preferences when compared to non-voters; (2) Does lower turnout favour, or harm, some parties; and (3) What would happen if turnout were to rise, or fall (Grofman et al., 1999). We are interested primarily in the third question. As this is a counterfactual it can be approached only in terms of questions one and two.

Many studies take the first approach and compare preferences of voters and non-voters. They assume that if the party preferences of the average abstainer are different from those of the average voter, then less than complete turnout will have some impact on the outcome of the election. If, on the other hand, abstainer preferences mirror voter preferences, then the level of voter turnout will have no consequences for the election outcome. This argument is flawed (Grofman et al., 1999). When we observe differences between the party preferences of voters and non-voters we cannot logically assume that somewhat higher turnout would favour the party that is underrepresented among the voters. It is not necessarily true that turnout that is a little higher than the current level would benefit the underrepresented party. Higher turnout could mean that additional supporters of the already 'overrepresented' party will vote and that potential supporters of the 'underrepresented' party will still remain at home.

Nor do we know how stable are the preferences of the non-voters. Non-voters' preferences might change if they participated. They might then be more informed. Alternatively, their involvement might result from a change in preferences. Any change in election outcome in the direction of the preferences of erstwhile non-voters is only likely under the assumption that the preferences of the non-voters would not change if they voted (Grofman et al., 1999, 360).

Of course there are other possible worries about low turnout, which are not directly related to electoral and policy outcomes (and which are not subject of this special issue). Low turnout may be problematic for democratic legitimacy because it may be a sign of dissatisfaction with democracy. In fact, much evidence suggests that dissatisfaction is not the main motive for non-voting. Many non-voters are fairly satisfied with how democracy works (Bennett and Resnick, 1990). Citizens do not vote either because they cannot (they lack the resources or capacity), or because they do not want to (they lack motivation) or because nobody asked them (mobilisation) (Verba et al., 1995, 3). Much nonvoting appears to stem from a lack of interest in, indifference towards and ignorance of elections or politics in general (Ragsdale and Rusk, 1993; Plane and Gershtenson, 2004). Politics is far from being a primary concern; family and friends, work and leisure matter much more for most people's everyday lives. The experience of two countries with notoriously low turnout, Switzerland and the US, moreover show that low turnout is not necessarily related to political instability. On this account there 
is little to suggest that low turnout is a sign of democracy in crises.

\section{Low turnout and its consequences}

We can distinguish between direct and indirect effects of low turnout. Direct effects occur when higher, or lower, turnout would lead to an election outcome than that with the current level of turnout. Indirect effects happen when elites lean their policies towards the voters and ignore the needs of the non-voters. While most studies assume a connection, these two effects are not necessarily connected. Even if there is a partisan bias due to low turnout, policy makers might nevertheless take the needs of the non-voters into account. The reverse may also be true: even if there is no observed partisan bias in low turnout elections, policies can be skewed in favour of the preferences of those who vote while those who do not are largely ignored.

\subsection{Direct effects on outcomes}

The articles in this special issue concentrate on the direct links between the outcomes of elections and popular votes and turnout. Much of the attention this question has received in the literature is directed at analysing the relation between election turnout and left-of-centre party (or candidate, as the case may be) vote share. It is assumed that people with lower socio-economic status tend to be less educated and less participative than the middle class; the latter, in contrast, tend to support more right-leaning parties. In addition, in the United States, but arguably not only there, this bias takes on ethnic and racial dimensions. Blacks, for example, who on average have lower socio-demographic status than whites, tend to support Democratic candidates, but they abstain at higher rates than middle-class whites (Wolfinger and Rosenstone, 1980, 90-91; Verba and Nie, 1972, 170-171). Similarly, educational attainment is positively correlated with voting propensity (Avey, 1989; Burnham, 1987; Piven and Cloward, 1989; Wolfinger and Rosenstone, 1980). While this logic is arguably most applicable to low turnout countries such as the United States, where socio-demographic differences in participation are particularly pronounced, a classbias in turnout has been reported for other countries and regions in the world as well (e.g. Dalton, 2002, 49-51). It appears to follow then, that if more people voted, left-of-centre parties and candidates would fare better in elections than they do at present.

One approach to resolving the question of who loses and who benefits from low turnout involves regressing the vote share of left-of-centre parties and candidates on aggregate turnout and a variety of control variables. This strategy has been used in relation to presidential, gubernatorial, senatorial, and House elections in the United States with mixed results. Radcliff (1994, 1995) claims that the Democratic vote share in presidential elections increases with voter turnout. However, Erikson (1995a,b) argues that proper specification of Radcliff's statistical models shows the relation between turnout and presidential Democratic vote share to be indistinct. Nagel and McNulty (1996) find that the relation between turnout and Democratic vote share in gubernatorial and senatorial races has varied over time, sometimes in a manner beneficial to Republican candidates, sometimes to Democrats, but most of the time just being statistically insignificant. Focussing on US House elections, DeNardo (1980) found that there is a conditional positive relationship between turnout and Democratic vote share (see also Tucker et al., 1986), but that the more important consequence of increased turnout is to harm the incumbent. For the rest of the world, Pacek and Radcliff (1995) find, in a cross-national study of advanced industrialised countries, that the vote share of left-leaning political parties increases with voter turnout. Similar findings have been made for cross-national surveys of developing countries (Aguilar and Pacek, 2000) and of post-communist countries in Central and Eastern Europe (Bohrer et al., 2000), as well as in single-country studies for Australia (McAllister, 1986), Britain (McAllister and Mughan, 1986), New Zealand (Nagel, 1988).

Studies using this approach estimate the political effect of differential turnout by pooling across a large collection of elections. It is reasonable to suppose, as Nagel and McNulty (1996) do, that turnout effects, if they exist, should be observable in election outcomes. Rather than rely on questionnaire-based information about the attitudes of voters and non-voters, this multipleelection regression approach examines the patterns in election results for evidence of turnout effects. However, it has been argued that this aggregate-level approach obscures the individuals who make voting choices and thus ignores the possibility that individual-specific factors may influence voting and abstention behaviour. The fact that elections reflect individual choices is thus easily lost (Herron, 1998, 6). Furthermore, there is an ecological inference problem inherent in the multiple-election regression approach to estimating turnout effects. Researchers cannot know the types of individuals that abstain in a given set of elections and must instead work solely with abstention rates. And while turnout rates in a group of elections may be 
similar, this does not imply necessarily that the types of individuals abstaining are necessarily the same in each of the elections (Grofman et al., 1999; Herron, 1998, 67). The appeals made by the same parties may well vary over time, and in fact the character of any party might well vary. This will increase the chance of different groups abstaining at different times, and thus increase the chance of biased inferences. A further problem with this approach is that when we study elections within the same country over time we cannot know from aggregate figures how many individual voters have changed their minds between two elections and how many of the potential voters have voted in both election. The expansion of the studies over time further increases the difficulties. The fact that individual-level studies have tended to produce negative findings (discussed below) while some aggregate-level regression models find positive correlations between turnout and left-of-centre vote share should alert us all the more to the potential gravity of the ecological inference problem.

The second approach to estimating turnout effects uses survey data as a basis for simulating the outcome were turnout to be higher, or lower. There are many ways in which this can be done. However, there is a general methodological challenge stemming from the sampling bias in survey research: survey respondents tend to vote at a higher rate than the real population. Two reasons are responsible for the over sampling. Non-voters tend to be more difficult to interview and some non-voters claim in surveys that they in fact have voted. The first problem can be tackled using weighting techniques in the analysis. The second is more difficult to control. In some countries, like the US, it is possible to correct for this bias because whether a survey respondent actually voted or not can be validated. But in most other countries it is not possible to validate reports of voting. What are the expected consequences of this sampling bias? One consequence is that we may exaggerate differences between voters and non-voters because we may have actual non-voters among the reported voters in a sample. In other words, we are more likely to find possible turnout effects that we would be if our data were to be validated. However, the bias might be counteracted by an opposing bias. We can assume that the most disconnected and transient members of the electorate do not tend to respond to surveys. If this is the case, it leads to a countervailing effect as we then underestimate differences between voters and non-voters. Thus, in general the problem of bias in survey data may not be severe.
Using survey data and comparing party or candidate choices of voters with measured or simulated preferences of the non-voters allows some conclusions to be drawn about the possible consequences of higher turnout (Lutz, 2006). Using data from the 1988 American National Election Study, Herron (1998) found that the Democrat presidential candidate, Dukakis, would have almost certainly won the election if turnout had been $100 \%$. In a similar analysis Citrin et al. (2003) use state-level exit polls and census data to estimate the partisan preferences of non-voters in Senate elections and then simulate the outcome of these elections under universal turnout. They find that while non-voters are generally more democratic than voters, the scarcity of close races means that very few election outcomes would have changed had everyone voted. Thus, although their results suggest that Democrats would fare better in a variety of alternative turnout scenarios, including full turnout of various ethnic, racial and income groups, few elections would actually have produced a different winner. The last word from this approach to date is a study that estimates the impact of differential turnout on the outcome of presidential elections from 1952 to 2000 using data from the National Election Study (NES) (Brunell and DiNardo, 2004). Their estimates are in line with the above findings that non-voters are, on average, slightly more likely to support the Democratic Party. Of the 13 presidential elections between 1952 and 2000 in only two-those of 1980 and 2000 - was the lead of the winning party sufficiently narrow that a different final outcome would have been likely. This has been reconfirmed recently by Martinez and Gill (2005).

Tóká (2002) extends this approach to a multitude of countries and elections. Using the June 2000 version of the Comparative Study of Electoral Systems (CSES) integrated micro-level data set, Tóka analyses turnout effects (alongside information effects) on outcomes of eighteen elections in as many countries. With this design he seeks to take into account the extent to which turnout effects may vary with political and institutional context. He reasons that varying correlations of party alignments with social cleavage lines or aspects of the institutional-electoral design may all firstly, influence the extent to which socially unequal turnout occurs in a given polity at a particular time, and secondly, then impacts on electoral outcomes. In order to model these factors explicitly, Tóka simulates election results projected on various counterfactual scenarios including $100 \%$ turnout, and then examines whether and to what extent the simulated election results would have systematically increased the weight on election outcomes 
of those preferences that are over-represented in groups showing below-average political involvement for reasons other than their political preferences (Tóká, 2002, 13-14). Tóka's analysis reveals only a small change, on average, in left-of-centre party fortunes if turnout increased to $100 \%$, result which he explains in terms of the overlap between the demographic correlates of vote choice and participation (Tóká, 2002, 38).

With its focus on individual elections, this approach allows for the important possibility that differential turnout effects may vary from election to election within one country, as well as between countries. However, there are limitations of this methodology. While it is useful to combine the advantages of individual-level analysis with the enhanced certainty and validity of actual behaviour and election results, this approach is restricted either to analysing one election at a time (Herron, 1998), to several elections of the same type and in one country for reasons of statistical control (Brunell and DiNardo, 2004; Citrin et al., 2003) or to modelling the effects of only a very small vector of variables which influence vote choice (Tóká, 2002). Thus, these studies must forgo either the ability to distinguish systematic and general turnout effects from the situational effects on voting behaviour, trends that persist across a large number of countries and elections, or the capacity to include more than a handful of variables in their model. Ideally we need an analysis of a heterogeneous sample of polities and elections if we are to generalise reliably about turnout effects in any election (Tóká, 2002, 24).

Parties may also respond to unequal participation: if some groups vote more than others, we could expect parties to adjust and put more efforts into mobilizing and targeting groups that are favourable disposed and show signs of higher turnout. There is evidence in US elections, for example, that parties do precisely this: they strategically direct their canvassing efforts to groups with higher turnout rates and higher probabilities to vote for their party (Wielhouwer, 1995). In the US black voters are less likely to be contacted by the Republican Party (Wielhouwer, 2000). Similarly parties canvass in districts where their support is fairly high and leave out districts with only little support for their parties (Huckfeld and Sprague, 1992). Studies have also found that people with higher socio-economic status are more likely to be contacted by parties than those from disadvantaged groups (Gershtenson, 2003) and younger voters are also less likely to be contacted (Wattenberg, 2003).

For actual voters, the mobilizing efforts of parties can have two different effects and these two effects can also be combined. The first is the effect mobilisation has on turnout and the second is the effect mobilisation has on the direction of a vote. Studies (mainly in the US) have not yet shown clear results. While some studies find that mobilisation has an effect on turnout, though not on the direction of the vote (Caldeira et al., 1985, 1990; Cox, 1999; Jackson, 1996, 1997; Rosenstone and Hansen, 1993; Wielhouwer and Lockerbie, 1994), other studies find a smaller effect on turnout and argue that the main effect is on the direction of the vote (Huckfeld and Sprague, 1992; Whitely and Seyd, 1994). If campaigning has a positive effect on turnout we can expect reinforcing consequences: some groups participate more because they are mobilized and because they participate more they are contacted by parties too. Very little research has been done on this outside the US but this question is beyond the focus of this special issue.

\subsection{Indirect effects on policies and campaigns}

While some kind of differential turnout can be expected to have some direct consequences for policy, via government formation, there may also be important indirect effects. These effects are indirect because they stem from the behaviour of political elites in response to historical and hence anticipated inequalities in political participation. If some groups are over-represented and others under-represented, this could imply that "public officials hear more from some kinds of citizens than from others and thus jeopardize the democratic norm of equal protection of interests" (Verba et al., 1995, 493). When participation is biased in terms of politically relevant characteristics, such as race or income, then policy outcomes may also be biased. If political elites pay more attention to the policy preferences and policy agendas of the voters, and if non-voters have different policy preferences and policy agendas, this will result in preferences of non-voters being systematically neglected, or at least getting a lower weighting in any democratic calculus. However, there is a counter argument. This is that political elites have to take into account the policy preferences and agendas of nonvoters because if they do not care enough about them, these people will show up at the next elections and may vote them out!

One way to examine the potential policy effects of non-voting is to compare political preferences of voters and non-voters. Many studies find little or no difference between the policy preferences of voters and non-voters in opinion polls (Shaffer, 1982; Teixeira, 1992; Wolfinger and Rosenstone, 1980, for the United States, 
and Studlar and Welch, 1986 for Great Britain). Gant and Lyons (1993) did find statistically significant differences but did so with respect to less than one-third of policy preference scales. Of the eleven issue dimensions on which voters and non-voters reflected statistically significant differences, eight were social welfare issues, and on all eight of these non-voters were more left-wing than voters. At the very least, they conclude, this suggests the possibility that increased electoral turnout of non-voters could lead to a different composition of the political agenda, or to a set of more left wing options on existing issues, thereby decreasing any class bias in voting and public policy (Gant and Lyons, 1993, 200). Bennett and Resnick (1990), although finding that the differences in policy positions are quite low, also find that there are significant differences on some domestic issues, mainly those dealing with spending on welfare programs (p. 771). But Highton and Wolfinger (2001) find no differences in most policy areas, with the exception of welfare policies.

All of these studies contrast the opinions of voters and non-voters. They do not deal directly with elite behaviour, or the fact that the existence of differences between the policy preferences of voters and non-voters does not necessarily mean that elites respond to those differences when making policy. However, an association between turnout and elite behaviour has been made by Hill and Leighley (1992), who find a negative relationship between an upper class bias in turnout and the generosity of indigenous state social welfare spending (see also Hill et al., 1995; Hill and Leighley, 1996; Ringquist et al., 1997). A similar result comes from a study by Hicks and Swank (1992), who find a positive link between levels of turnout and the welfare efforts of governments in western democracies. Mueller and Stratmann (2003) also find links between participation and income distribution; the higher participation is in a country, the more redistributive are policies (although at the price of lower total income and reduced economic growth). Most recently Martin (2003) found that in the US counties with higher turnout receive larger amounts of federal expenditure.

\section{New findings of the articles}

The main finding of this volume is that turnout does not matter a great deal, no matter what method, dataset or period of time the authors apply. The various contributions each demonstrate that overall effects are minimal. Where they can be observed, they do not point in the originally expected direction that low turnout harms left-of-centre parties. We can conclude that one of the main worries about low turnout expressed by Lijphart (1997) among others is not born out in empirical analysis.

The articles vary in the types of elections and countries explored, thus broadening the debate beyond the largely Anglo-American basis of most previous research. General elections in Norway, the UK and Canada, referendums in Switzerland and European Parliament elections are all explored, while there are also three extensive comparative studies of general elections.

The contributions vary in the approaches used to explore the consequences of low turnout. Each of the broad strategies discussed above are used. One approach focuses mainly on individuals. Most of our articles use opinion surveys to consider whether voters and non-voters differ in any significant way on the dimension of partisan choice but employ a variety of survey-based evidence, which they use in different ways. Van der Eijk and van Egmond use a direct question to ask about voting in a hypothetical coincident election to explore the impact of low turnout in European parliament elections and Lutz uses a similar survey question to explore the impact of differential turnout in Swiss referenda. Pettersen and Rose use a party thermometer question to probe the partisan consequences of higher mobilisation among non-voters while Bernhagen and Marsh treat the probable vote choice of non-voters as missing data to be inferred from the covariation of the choices of those who did report a vote and their political preferences and socio-demographic characteristics. Finally, Rubenson et al. examine the policy preference of non-voters as one way of assessing vote choice.

In contrast to this individual level approach, a second method involves regressing the vote share of left-ofcentre parties and candidates on aggregate turnout and a variety of control variables. As already noted, this strategy has been used in relation to US elections and in cross-national studies. Fisher explores this relationship using both a cross-country time series framework as well as making use of UK constituency level data across a substantial time period and the set of European Parliament elections.

Pettersen and Rose explore the effects of somewhat higher turnout in high turnout elections and van der Eijk and van Egmond look at the effects of declining turnout while the other survey-based articles consider full turnout, or changes up to full turnout. As discussed above, counterfactual estimates of the effects of more modest turnout increases and decreases should not assume that a random process determines which additional voters participate and which voters drop out. 
Rosema shows that individual probabilities to participate vary a lot and that there is not always a linear relationship between the different social and political characteristics and probability of voting. Bernhagen and Marsh also take into account different probabilities of voting by way of the stepwise addition of ever less likely voters.

While the methods and data employed in these articles vary, the conclusions reached do not. The articles all agree that possible increases and decreases in turnout have little impact on election results. There is no significant bias against the left that would be redressed if only turnout were higher. We can look at these conclusions in a little more detail, taking the comparative articles first. Bernhagen and Marsh concentrate on effects of $100 \%$ turnout on electoral outcomes and conclude that they would be small for the most part. Not surprisingly, the biggest effects tend to be found where turnout is lowest The main beneficiaries of full turnout would be small parties and non-incumbent parties but in most cases the 'winners' remained unchanged and the gains of the smallest parties might still leave them without parliamentary representation. Van der Eijk and van Egmond come to a similar conclusion that effects are generally weak although they examine a smaller range of turnout variation, contrasting turnout in European Parliament elections with that in general elections. Both articles point out that while differential turnout can and in some instances does have very significant consequences, such cases are relatively rare. In contrast to Bernhagen and Marsh, van der Eijk and van Egmond find no systematic pattern of winners and losers and they conclude that turnout effects are largely idiosyncratic. Fisher switches the focus to aggregate data and draws on a broad range of comparative data sets. He concludes that while there is superficial support from an OECD data set for the proposition that left parties do better where turnout is higher, the proposition that such parties would do better if turnout were higher-or worse if it fell-could not be sustained since there was no link between change in turnout levels and change in the left share of the vote. Analysis of European Parliament election results confirmed that pattern, in contrast to earlier results obtained by Pacek and Radcliff (2003) whose methodology is criticised by Fisher. Moreover, Fisher's extensive analysis of British data also reinforced the weakness of the simple link between left party strength and higher turnout. If these findings are all generally negative, they nonetheless run counter to a widespread acceptance of the positive link between turnout and left leaning forces.
The articles by Rubenson, Blais, Gidengill, Nevitte and Fournier and by Pettersen and Rose both limit the analysis to a particular country. Rubenson et al use Canadian data to explore differences between voters and non-voters and, using policy measures to estimate likely partisanship, find scant evidence for the contention that voters and non-voters hold different views and that election outcomes would be very different with full turnout. Differences between actual outcomes and those simulated under full turnout were typically less than $2 \%$, even for the larger parties.

In contrast to the paper by Rubenson et al., Pettersen and Rose, like van der Eijk and van Egmond (and Fisher) are concerned primarily with the impact on the result of turnout by those that might have been expected to vote, rather than all non-voters. They find, using data from Norwegian national election studies, that nothing much would have changed and that there is little sign of differential turnout by the supporters of a particular party having a significant impact on the outcome. Their results echo those of Bernhagen and Marsh and van der Eijk and van Egmond in showing that falling levels of turnout in practice do seem to create more opportunity for differential turnout to manifest itself, but also reaffirm the conclusions of other articles that turnout effects are generally slight. They also find no evidence that larger parties, more extreme parties or smaller parties would benefit from a somewhat higher turnout. In short, the idea that there are significant pockets of easy-to-mobilise potential support for party leaders to exploit gets no support from this article.

Rosema's article also takes a comparative approach but focuses more on the way voters make their decisions and the implications of this for our understanding of the functions of elections. He explores whether turnout levels have implications for the relative distribution of different types of voters: those who hold the government accountable or those who vote on ideological grounds as opposed to those whose choice seems more idiosyncratic. The first two types of voters illustrate the working of the classic accountability and mandate functions of elections while the third fulfils only the democratic norm of involvement and participation, perhaps at the expense of the other two. Rosema finds that the impact of levels of turnout on the active electorate in these terms is slight. However, the fact that accountability and ideologically patterned voting is slightly more common when turnout is low suggests that the consequences of lower turnout are not uniformly gloomy from the perspective of the democratic function of elections. 
Finally, Lutz shifts the focus from electoral democracy to direct democracy by looking at the impact of differential turnout on Swiss referendums. He also adds information to the mix. He finds evidence of a turnout bias in the outcome of popular votes but shows this is not large, and is smaller in the more 'important' votes. Even so, the outcome of some close and important votes could have been different with higher turnout. He does not find any general bias against the more 'left-wing' options. Information enters the equation in an interesting manner. Non-voters tend to have less information and are more right wing in their views. Hence higher turnout might benefit the right. However, more informed voters are more left wing and, arguably, higher turnout could only be achieved (short of compulsory voting) by raising interest and information. If so, higher turnout might then benefit the right much less and perhaps the left rather more than might be expected on a simple comparison of voters and nonvoters. This last article raises the question explicitly of how turnout is to be raised and whether or not the process of increasing turnout might in itself change our estimates of how people might vote. Lutz suggests that, to the extent that information matters in mobilisation, we may underestimate the impact of increased turnout and so indicates at least one path for further research in this area.

\section{References}

Aguilar, E.E., Pacek, A., 2000. Macroeconomic conditions, voter turnout, and the working class/economically disadvantaged party vote in developing countries. Comparative Political Studies 33, 995-1017.

Avey, M.J., 1989. The Demobilization of American Voters. A Comprehensive Theory of Voter Turnout. Greenwood Press, New York, Westport, CT, London.

Barber, B.R., 1984. Strong Democracy. Participatory Politics for a New Age. University of California Press, Berkeley, CA.

Bennett, S.E., Resnick, D., 1990. The implications of nonvoting for democracy in the United States. American Journal of Political Science 34, 771-802.

Blais, A., Gidengill, E., Nevitte, N., Nadeau, R., 2004. Where does turnout decline come from? European Journal of Political Research 43, 221-236.

Bohrer, R.E., Pacek, A.C., Radcliff, B., 2000. Electoral participation, ideology, and party politics in post-communist countries. Journal of Politics 62, 1161-1172.

Brunell, T.L., DiNardo, J., 2004. A propensity score reweighting approach to estimating the partisan effects of full turnout in American presidential elections. Political Analysis 12, 28-45.

Burnham, W.D., 1987. The turnout problem. In: Reichley, J.A. (Ed.), Elections American Style. Brookings, Washington, DC.

Caldeira, G.A., Clausen, A.R., Patterson, S.C., 1990. Partisan mobilization and electoral participation. Electoral Studies 9, 191-204.
Caldeira, G.A., Patterson, S.C., Markko, G.A., 1985. The mobilization of voters in congressional elections. Journal of Politics 47, 490-509.

Cavanagh, T.E., 1981. Changes in American voter turnout. Political Science Quarterly 96, 53-65.

Citrin, J., Schickler, E., Sides, J., 2003. What if everyone voted? Simulating the impact of increased turnout in Senate elections. American Journal of Political Science 47, 75-90.

Cox, G.W., 1999. Electoral rules and the calculus of mobilization. Legislative Studies Quarterly 24, 387-419.

Dalton, R.J., 2002. Citizen Politics. Public Opinion and Political Parties in Advanced Industrial Democracies. Chatham House Publishers, New York, London.

DeNardo, J., 1980. Turnout and the vote: the joke's on the Democrats. American Political Science Review 74, 406-420.

Erikson, R.S., 1995a. Pooling and statistical control: a rejoinder to Radcliff. American Politics Quarterly 23, 404-408.

Erikson, R.S., 1995b. State turnout and presidential voting: a closer look. American Politics Quarterly 23, 387-396.

Franklin, M.N., 2002. The dynamics of electoral participation. In: LeDuc, L., Niemi, R.G., Norris, P. (Eds.), Comparing Democracies 2. New Challenges in the Study of Elections and Voting. Sage, London, Thousand Oaks, New Dehli, pp. 148-168.

Gant, M.M., Lyons, W., 1993. Democratic theory, non-voting, and public policy: the 1972-1988 Presidential elections. American Politics Quarterly 21, 185-204.

Gershtenson, J., 2003. Mobilization strategies of the Democrats and Republicans, 1956-2000. Political Research Quarterly 56, 293-308.

Gray, M., Caul, M., 2000. Declining voter turnout in advanced industrial democracies, 1950 to 1997 . The effects of declining group mobilization. Comparative Political Studies 33, 1091-1122.

Grofman, B., Owen, G., Collet, C., 1999. Rethinking the partisan effects of higher turnout: so what's the question? Public Choice 99, 357-376.

Herron, M.C., 1998. The presidential elections of 1988: low turnout and the defeat of Micheal Dukakis. Working paper, Political Methodology.

Hicks, A.M., Swank, D.H., 1992. Politics, institutions, and welfare spending in industrialized democracies, 1960-82. American Political Science Review 86, 658-674.

Highton, B., Wolfinger, R.E., 2001. The political implications of higher turnout. British Journal of Political Science 31, 179-192.

Hill, K.Q., Leighley, J.E., 1992. The policy consequences of class bias in state electorates. American Journal of Political Science 36, 351-365.

Hill, K.Q., Leighley, J.E., 1996. Political parties and class mobilization in contemporary United States elections. American Journal of Political Science 40, 787-804.

Hill, K.Q., Leighley, J.E., Hinton-Andersson, A., 1995. Lower-class mobilization and policy linkage in the U.S. states. American Journal of Political Science 39, 75-86.

Huckfeld, R., Sprague, J., 1992. Political parties and electoral mobilization: political structure, social structure, and the party canvass. American Political Science Review 86, 70-86.

Jackson, R.A., 1996. The mobilization of congressional electorates. Legislative Studies Quarterly 21, 425-445.

Jackson, R.A., 1997. The mobilization of U.S. state electorates in the 1988 and 1990 elections. Journal of Politics 59, 520-537.

Lijphart, A., 1997. Unequal participation: democracy's unresolved dilemma. Presidential address, American Political Science Association, 1996. American Political Science Review 91, 1-14. 
Lutz, G., 2006. Participation, Information and Democracy. The Consequences of Low Levels of Participation and Information for the Functioning of Democracy. Lit-Verlag, Hamburg.

Martin, P.S., 2003. Voting's rewards: voter turnout, attentive publics, and congressional allocation of federal money. American Journal of Political Science 47, 110-127.

Martinez, M.D., Gill, J., 2005. The effects of turnout on partisan outcomes in U.S. presidential elections 1960-2000. Journal of Politics 67, 1248-1274.

McAllister, I., 1986. Compulsory voting, turnout and party advantage in Australia. Politics 21, 89-93.

McAllister, I., Mughan, A., 1986. Differential turnout and party advantage in British General Elections. Electoral Studies 5, $143-152$.

Mueller, D.C., Stratmann, T., 2003. The economic effects of democratic participation. Journal of Public Economics 87, 2129-2255.

Nagel, J.H., 1988. Voter turnout in New Zealand General Elections, 1928-1988. Political Science 40, 16-38.

Nagel, J.H., McNulty, J.E., 1996. Partisan effects of voter turnout in senatorial and gubernatorial elections. American Political Science Review 90, 780-793.

Norris, P., 2002. Democratic Phoenix: Reinventing Political Activism. Cambridge University Press, Cambridge.

Pacek, A., Radcliff, B., 1995. Turnout and the vote for left-of-center parties: a cross-national analysis. British Journal of Political Science 25, 137-143.

Pacek, A.C., Radcliff, B., 2003. Voter participation and party-group fortunes in European Parliament elections, 1979-1999: a crossnational analysis. Political Research Quarterly 56, 91-95.

Pateman, C., 1970. Participation and Democratic Theory. University Press, Cambridge.

Piven, F.F., Cloward, R.A., 1989. Why Americans Don't Vote. Pantheon Books, New York.

Plane, D.L., Gershtenson, J., 2004. Candiates' ideological locations, abstention, and turnout in U.S. midterm Senate elections. Political Behaviour 26, 69-93.

Radcliff, B., 1994. Turnout and the Democratic vote. American Politics Quarterly 22, 259-276.

Radcliff, B., 1995. Turnout and the Democratic vote revisted: a reply to Erikson. American Politics Quarterly 23, 397-403.
Ragsdale, L., Rusk, J.G., 1993. Who are nonvoters? Profiles from the 1990 Senate elections. American Journal of Political Science 37, 721-746.

Ringquist, E.J., Hill, K.Q., Leighley, J.E., Hinton-Anderson, A., 1997. Lower-class mobilization and policy linkage in the U.S. states: a correction. American Journal of Political Science 41, 339-344.

Rosenstone, S.J., Hansen, J.M., 1993. Mobilization, Participation, and Democracy in America. Macmillan, New York.

Salisbury, R.H., 1975. Research on political participation. American Journal of Political Science 19, 323-341.

Shaffer, S.D., 1982. Policy differences between voters and nonvoters in American elections. Western Political Quarterly 35, 496-510.

Studlar, D.T., Welch, S., 1986. The policy opinions of British nonvoters: a research note. European Journal of Political Research 14, 139-148.

Teixeira, R.A., 1992. The Disappearing American Voter. The Brookings Institution, Washington.

Tóká, G., 2002. Turnout: what moves it and does it really matter. Paper presented at the 2001 General Conference of the ECPR, Canterbury, University of Kent.

Tucker, H.J., Vedlitz, A., DeNardo, J., 1986. Does heavy turnout help Democrats in Presidential elections? American Political Science Review 80, 1291-1304.

Verba, S., Nie, N.H., 1972. Participation in America: Political Democracy and Social Equality. Harper and Row, New York.

Verba, S., Schlozman, K.L., Brady, H.E., 1995. Voice and Equality. Civic Voluntarism in American Politics. Harvard University Press, Cambridge, London.

Whitely, P.F., Seyd, P., 1994. Local party campaigning and electoral mobilization in Britain. Journal of Politics 56, 242-252.

Wielhouwer, P.W., 1995. Strategic canvassing by the political parties. American Review of Politics 16, 213-238.

Wielhouwer, P.W., 2000. Releasing the fetters: parties and mobilization of the African-American electorate. Journal of Politics 62, 206-222.

Wielhouwer, P.W., Lockerbie, B., 1994. Party contacting and political participation, 1952-90. American Journal of Political Science 38, 211-229.

Wolfinger, R.E., Rosenstone, S.J., 1980. Who Votes? Yale University Press, New Haven, CT, London. 